\title{
Influence of Primers Containing Cupric Ion on Bonding of Dentin Treated with Phosphoric Acid
}

\author{
Yohji IMAI and Ryuichiro IKEMURA \\ Institute for Medical and Dental Engineering, Tokyo Medical and Dental University, \\ 2-3-10, Kanda-Surugadai, Chiyoda-ku, Tokyo 101, Japan
}

Received January 31, 1994/Accepted April 15, 1994

\begin{abstract}
A primer containing cupric [Cu (II)] ions that promoted the interfacial initiation of polymerization from dentin surfaces was studied. Bovine dentin surfaces were treated with $10 \%$ phosphoric acid, then with a $\mathrm{Cu}$ primer consisting of aqueous 35\% 2-hydroxyethyl methacrylate (HEMA) containing $0.03 \%$ cupric salt, and finally bonded with 4-META/MMA-PMMA resin initiated with oxidized tributylborane (TBBO). The use of the $\mathrm{Cu}$ primer resulted in a mean bond strength of $12.5 \mathrm{MPa}$ compared with $3.8 \mathrm{MPa}$ without the primer and $6.3 \mathrm{MPa}$ using a 35\% HEMA primer without $\mathrm{Cu}$. The $\mathrm{Cu}$ primer produced a bond strength of $13.5 \mathrm{MPa}$ even without 4-META in the resin system. Use of the $\mathrm{Cu}$ primer should simplify the bonding procedure since enamel and dentin can be etched simultaneously with $10 \%$ phosphoric acid.
\end{abstract}

Key words : Dentin bonding, Primer, Phosphoric acid

\section{INTRODUCTION}

There is considerable interest and activity in dentin bonding systems and many products are available. However, adhesion to dentin requires further research to improve clinical performance ${ }^{1)}$. Most studies of dentin bonding systems have been directed to adhesion -promoting monomers, treatment agents such as etchant, cleanser, and conditioner, as well as primers. The role of polymerization initiator systems in bonding has been studied to a lesser degree, but we and others have stressed the importance of polymerization initiator systems and the interfacial initiation of polymerization to achieve effective adhesion to dentin and to reduce marginal gap and microleakage ${ }^{2}$.

We have proposed two approaches for causing interfacial initiation of polymerization from the dentin surface. These are the use of metal ions such as ferric or cupric ions adsorbed onto dentin as a component of redox-type initiators and of initiators, having high affinity for dentin.

We investigated the influence of primers containing cupric ions [Cu (II)], that initiate and promote polymerization at the dentin interface, upon dentin bonding after etching with phosphoric acid. 


\section{MATERIALS AND METHODS}

\section{Materials}

The following were used without purification*: 2-hydroxyethyl methacrylate (HEMA), methyl methacrylate (MMA), phosphoric acid, citric acid, ferric chloride, and cupric salts $[\mathrm{Cu}$ (II)] of acetate, acetylacetonate, chloride, and nitrate. Cupric methacrylate was prepared from sodium methacrylate and cupric chloride. Oxidized tributylborane (TBBO), 4-methacryloyloxyethoxycarbonylphthalic acid anhydride (4-META), and poly (methylmethacrylate) (PMMA) powder were commercially available**.

Two resin cement formulations (4-META/MMA-PMMA and MMA-PMMA) were prepared: a $1: 1(\mathrm{w} / \mathrm{w})$ mixture (this ratio was established by means of the brush-on -technique used in the present resin system) of PMMA and MMA containing $10 \mathrm{wt} \%$ TBBO with or without $5 \mathrm{wt} \%$ 4-META. The cement containing 4-META was practically the same as the commercially available material\#.

\section{Reagents}

These included $5,7,10,15$, and $40 \mathrm{wt} \%$ phosphoric acid and a mixture of $10 \mathrm{wt} \%$ citric acid and $3 \%$ ferric chloride.

\section{Primers}

Five primers containing $\mathrm{Cu}$ (II) ions were prepared by adding $0.03 \mathrm{wt} \% \mathrm{Cu}$ (II) acetate, acetylacetonate, chloride, methacrylate and nitrate in aqueous $35 \mathrm{wt} \%$ HEMA as a control primer.

\section{SEM examination of tooth structures}

One drop (about $0.05 \mathrm{~mL}$ ) of $5,7,10,15$, or $40 \mathrm{wt} \%$ phosphoric acid was applied to the finished tooth surfaces described below for 15,30 , or $60 \mathrm{~s}$. Immediately thereafter, the surface was rinsed with a stream of water for $20 \mathrm{~s}$, dried under compressed air for $20 \mathrm{~s}$ and then in vacuo. The specimens were sputtercoated with gold and examined under a scanning electron microscope\#.

\section{Measurement of bond strength}

Bovine anterior teeth were ground on a model trimmer to expose adequate enamel or dentin surface for bonding. The exposed surfaces were then finished with 600 -grit abrasive paper, treated with a drop (approximately $0.05 \mathrm{~mL}$ ) of $5,7,10,15$, or $40 \mathrm{wt} \%$ phosphoric acid or the mixture of $10 \%$ citric acid and $3 \%$ ferric chloride for $30 \mathrm{~s}$, rinsed with water for $20 \mathrm{~s}$ and air -dried for $20 \mathrm{~s}$. Adhesive masking tape with a 5-mm diameter hole was attached to the surface to control the adhesion area. The $\mathrm{Cu}$ primer was applied with a small brush to the tooth surface and left for $30 \mathrm{~s}$. An acrylic rod, having 8-mm diameter, 30-mm length, and a hole in one end through which a metal pin was passed to attach it to a testing machine, was bonded perpendicularly to the surface with the 4-META/MMA-PMMA or MMA-PMMA resin cement. The specimen was left for $15 \mathrm{~min}$ in air at room temperature, stored in distilled water at $37^{\circ} \mathrm{C}$ for $24 \mathrm{~h}$, then tensile failure was tested on an Instron-type universal

* Nacalai Tesque Co., Kyoto, Japan

* * Sun Medical Co., Moriyama, Shiga, Japan

\# Super-Bond C\&B, Sun Medical Co., Moriyama, Shiga, Japan

\# Model 2300, Hitachi Co., Tokyo, Japan 


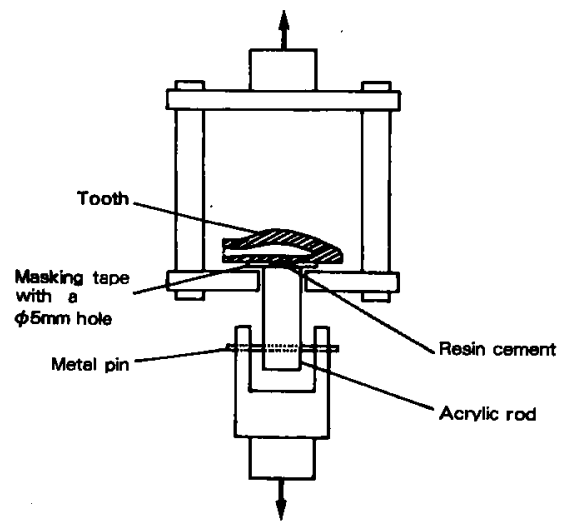

Fig. 1 Assembly used to test tensile bond strength.

testing machine ${ }^{\otimes}$ with a crosshead speed of $2 \mathrm{~mm} / \mathrm{min}$. The assembly used for the test is schematically shown in Fig. 1.

After the bond tests, the fracture surfaces were examined to identify the mode of failure. Failure at the tooth/resin interface constituted adhesive bond failure. That which occurred within the resin cement and/or tooth substrate constituted cohesive failure, whereas that partly at the interface and partly within the cement was termed mixed failure.

Five specimens were tested in each group. The data were evaluated by means of the analysis of variance and Duncan's multiple range test at the $5 \%$ level of significance.

\section{RESULTS}

Bovine tooth surfaces finished with 600 -grit abrasive paper were treated with $5,7,10,15$ or $40 \%$ phosphoric acid (PA) for 15,30 , or $60 \mathrm{~s}$ and examined under a scanning electron microscope (SEM). The scanning electron micrographs revealing the effects upon the enamel and dentin surfaces exposed to this procedure for $30 \mathrm{~s}$, are shown in Figs. 2 and 3. The enamel surfaces were etched to various degrees that were almost proportional to the PA concentration and the length of exposure. The dentin surfaces exhibited a gradual decrease in the amount of plug material in the tubules and gradual widening of the tubule orifices, as the strength of the acid and the length of treatment increased.

The effect of the PA concentration used to pretreat the enamel surface on the bond strength of 4-META/MMA-TBBO resin is shown in Table 1 . The mean bond strength ranged from 12.0 to $16.8 \mathrm{MPa}$, which was not significantly different at the 0.05 level. With or without $\mathrm{Cu}$ primer, the bond strength to surfaces etched with $10 \% \mathrm{PA}$ were 19.2 and 16.8 $\mathrm{MPa}$, respectively, which were not statistically different.

Table 2 shows the effects of the $\mathrm{Cu}$ primer and the concentrations of PA on the bonding

a Autograph AGS 1000A, Shimadzu Co., Kyoto, Japan 

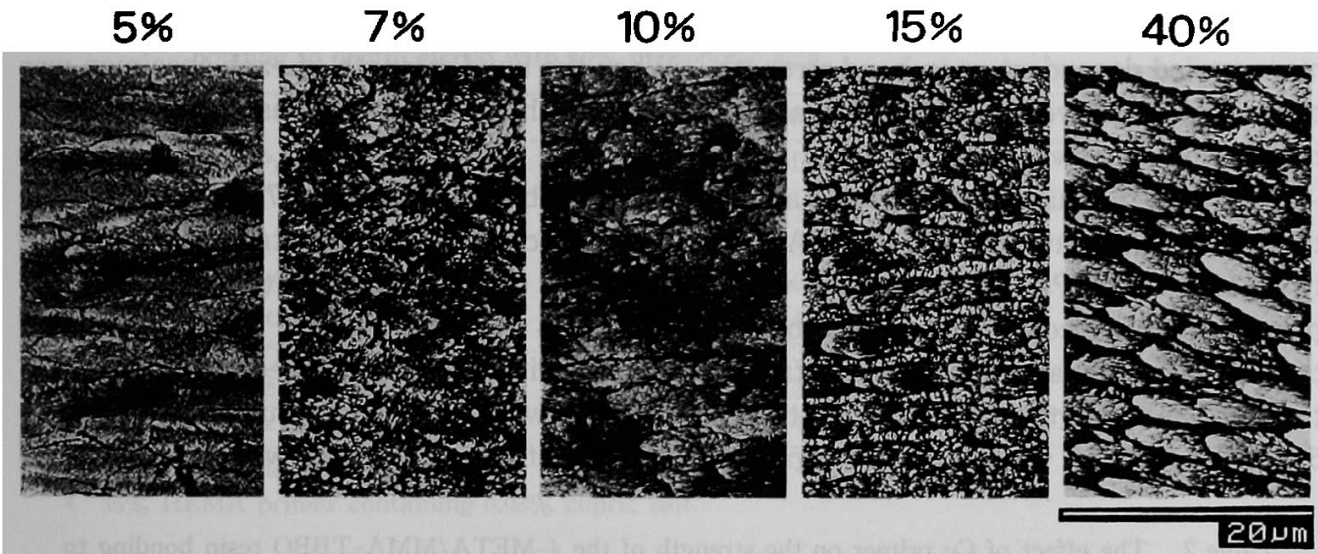

Fig. 2 Enamel surfaces exposed to $5,7,10,15$, or $40 \%$ phosphoric acid for $30 \mathrm{~s}$.

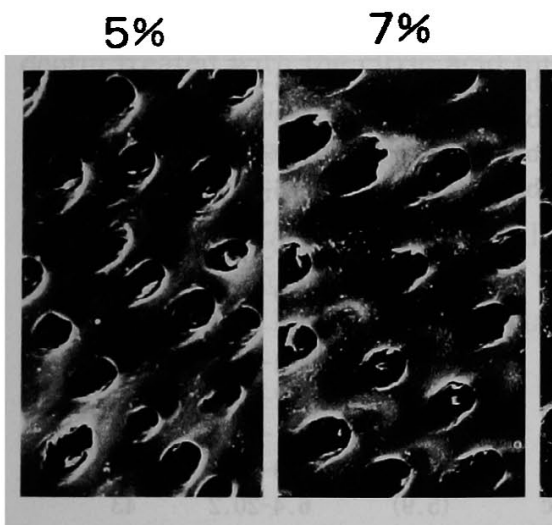

$10 \%$

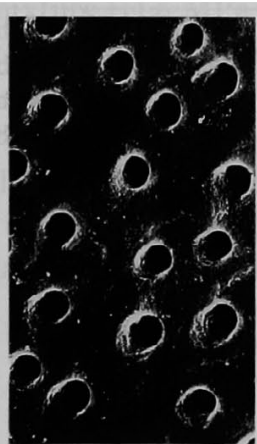

$15 \%$

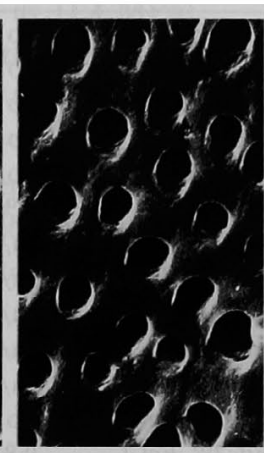

$40 \%$

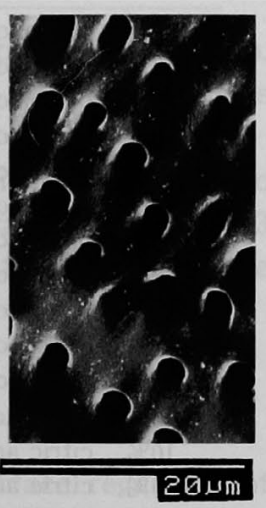

Fig. 3 Dentin surfaces exposed to $5,7,10,15$, or $40 \%$ phosphoric acid for $30 \mathrm{~s}$.

Table 1 The bond strength of 4-META/MMA-TBBO resin to enamel treated with various concen trations of phosphoric acid

\begin{tabular}{|c|c|c|c|c|c|}
\hline \multirow{2}{*}{\multicolumn{2}{|c|}{ Treatment }} & \multicolumn{3}{|c|}{ Bond strength (MPa) } & \multirow{2}{*}{$\begin{array}{c}\mathrm{CV} * * \\
(\%)\end{array}$} \\
\hline & & Mean* & $(\mathrm{SD}) * *$ & Range & \\
\hline $5 \%$ & phosphoric acid & $12.0 \mathrm{a}$ & $(2.7)$ & $9.3-15.2$ & 23 \\
\hline $7 \%$ & phosphoric acid & $15.1 \mathrm{ab}$ & $(1.8)$ & $12.7-17.5$ & 12 \\
\hline $10 \%$ & phosphoric acid & $16.8 \mathrm{ab}$ & $(3.6)$ & $13.7-22.7$ & 21 \\
\hline $15 \%$ & phosphoric acid & $14.5 \mathrm{ab}$ & $(3.7)$ & $10.0-19.9$ & 26 \\
\hline $40 \%$ & phosphoric acid & $14.9 \mathrm{ab}$ & $(4.6)$ & $9.5-22.1$ & 31 \\
\hline $10 \%$ & phosphoric acid" & $19.2 \mathrm{~b}$ & $(2.0)$ & $17.2-22.2$ & 10 \\
\hline $10 \%$ & citric acid $/ 3 \% \mathrm{FeCl}_{3}$ & $15.9 \mathrm{ab}$ & $(4.1)$ & $11.4-20.4$ & 26 \\
\hline
\end{tabular}

* Means with the same letters were not significantly different at the level of 0.05

* * SD, standard deviation; CV, coefficient of variation

\# $35 \%$ HEMA primer containing $0.03 \%$ cupric chloride was used thereafter 
of 4-META/MMA-TBBO resin to dentin. The mode of failure of the bonding test specimens varied dependent upon bond strength. When the bond strength of each specimen was below $4 \mathrm{MPa}$, between 4 and $9 \mathrm{MPa}$, and above $9 \mathrm{MPa}$, the failure mode was mostly adhesive, mixed, and cohesive, respectively.

Without the $\mathrm{Cu}$ primer, the resin alone resulted in a bond strength of 1.7-4.4 $\mathrm{MPa}$. When the dentin was treated with $7-40 \% \mathrm{PA}$, the $\mathrm{Cu}$ primer increased the bond strength significantly to 11.3-13.7 $\mathrm{MPa}$. These values were about three times as high as those without the primer and were comparable to the bond strength (11.4 $\mathrm{MPa}$ ) obtained in bonding to dentin treated with standard citric acid containing ferric chloride as recommended by the manufacturer. The strength of the bonding to dentin treated with 5\% PA and $\mathrm{Cu}$ primer was only 6.2 $\mathrm{MPa}(\mathrm{p}<0.05)$, which was not significantly different from the value without the primer

Table 2 The effect of $\mathrm{Cu}$ primer on the strength of the 4-META/MMA-TBBO resin bonding to dentin treated with various concentrations of phosphoric acid

\begin{tabular}{|c|c|c|c|c|c|c|}
\hline & \multirow[b]{2}{*}{ Treatment } & \multirow[b]{2}{*}{ Primer } & \multicolumn{3}{|c|}{ Bond strength (MPa) } & \multirow{2}{*}{$\begin{array}{c}\mathrm{CV}^{* *} \\
(\%)\end{array}$} \\
\hline & & & Mean* & $(\mathrm{SD}) * *$ & Range & \\
\hline $5 \%$ & phosphoric acid & No & $3.7 \mathrm{ab}$ & $(1.1)$ & $2.6-5.3$ & 30 \\
\hline $7 \%$ & phosphoric acid & No & $4.4 \mathrm{ab}$ & $(3.6)$ & $0.8-9.2$ & 82 \\
\hline $10 \%$ & phosphoric acid & No & $4.2 \mathrm{ab}$ & $(2.1)$ & $1.0-6.5$ & 50 \\
\hline $15 \%$ & phosphoric acid & No & $3.9 \mathrm{ab}$ & $(2.8)$ & $0.6-8.1$ & 72 \\
\hline $40 \%$ & phosphoric acid & No & $1.7 \mathrm{a}$ & $(0.8)$ & $0.9-2.7$ & 47 \\
\hline $10 \%$ & phosphoric acid & $35 \%$ HEMA & $6.3 \mathrm{~b}$ & $(3.7)$ & $1.7-10.8$ & 60 \\
\hline $5 \%$ & phosphoric acid & $\mathrm{Cu} / \mathrm{HEMA}^{\#}$ & $6.2 \mathrm{~b}$ & $(2.4)$ & $3.0-9.1$ & 39 \\
\hline $7 \%$ & phosphoric acid & $\mathrm{Cu} / \mathrm{HEMA}^{\#}$ & $11.3 \mathrm{c}$ & $(4.5)$ & $7.1-16.2$ & 40 \\
\hline $10 \%$ & phosphoric acid & $\mathrm{Cu} / \mathrm{HEMA}^{\#}$ & $12.5 \mathrm{c}$ & $(3.4)$ & $8.4-18.5$ & 27 \\
\hline $15 \%$ & phosphoric acid & $\mathrm{Cu} / \mathrm{HEMA}^{\#}$ & $12.9 \mathrm{c}$ & $(4.1)$ & $9.7-20.1$ & 32 \\
\hline $40 \%$ & phosphoric acid & $\mathrm{Cu} / \mathrm{HEMA}^{\#}$ & $13.7 \mathrm{c}$ & $(3.1)$ & $9.1-18.0$ & 23 \\
\hline $10 \%$ & citric acid $/ 3 \% \mathrm{FeCl}_{3}$ & No & $11.4 \mathrm{c}$ & $(4.1)$ & $5.9-16.4$ & 36 \\
\hline $10 \%$ & citric acid $/ 3 \% \mathrm{FeCl}_{3}$ & $35 \%$ HEMA & $13.7 \mathrm{c}$ & $(5.9)$ & $6.4-20.2$ & 43 \\
\hline $10 \%$ & citric acid $/ 3 \% \mathrm{FeCl}_{3}$ & $\mathrm{Cu} / \mathrm{HEMA}^{\#}$ & $11.8 \mathrm{c}$ & $(6.3)$ & $5.3-20.2$ & 53 \\
\hline
\end{tabular}

* Means with the same letters were not significantly different at the level of 0.05

** SD, standard deviation ; CV, coefficient of variation

\# $35 \%$ HEMA primer containing $0.03 \%$ cupric chloride

Table 3 The effect of 4-META on the strength of the MMA-TBBO resin bonding to dentin

\begin{tabular}{|c|c|c|c|c|c|c|c|}
\hline & \multirow[b]{2}{*}{ Treatment } & \multirow[b]{2}{*}{ Primer } & \multirow[b]{2}{*}{ 4-META } & \multicolumn{3}{|c|}{ Bond strength (MPa) } & \multirow{2}{*}{$\begin{array}{c}\mathrm{CV} * * \\
(\%)\end{array}$} \\
\hline & & & & Mean* & $(\mathrm{SD}) * *$ & Range & \\
\hline $10 \%$ & phosphoric acid & No & No & $3.3 \mathrm{a}$ & $(2.4)$ & $0.2-5.7$ & 73 \\
\hline $10 \%$ & phosphoric acid & No & Yes & $3.8 \mathrm{a}$ & $(2.2)$ & $1.0-6.5$ & 58 \\
\hline $10 \%$ & phosphoric acid & $35 \%$ HEMA & No & $5.4 \mathrm{a}$ & $(2.3)$ & $2.0-7.8$ & 43 \\
\hline $10 \%$ & phosphoric acid & $35 \%$ HEMA & Yes & $6.3 \mathrm{ab}$ & $(3.7)$ & $1.7-10.8$ & 60 \\
\hline $10 \%$ & phosphoric acid & $\mathrm{Cu} / \mathrm{HEMA}^{\#}$ & No & $13.5 \mathrm{c}$ & $(5.3)$ & $8.1-21.2$ & 39 \\
\hline $10 \%$ & phosphoric acid & $\mathrm{Cu} / \mathrm{HEMA}^{\#}$ & Yes & $12.5 \mathrm{c}$ & $(3.4)$ & $8.4-18.5$ & 27 \\
\hline $10 \%$ & citric acid $/ 3 \% \mathrm{FeCl}_{3}$ & No & No & $11.0 \mathrm{bc}$ & $(4.1)$ & $4.0-14.3$ & 37 \\
\hline $10 \%$ & citric acid $/ 3 \% \mathrm{FeCl}_{3}$ & No & Yes & $11.4 \mathrm{c}$ & $(4.1)$ & $5.9-16.4$ & 36 \\
\hline
\end{tabular}

$*^{*} *^{*}, \#$ See Table 2 
Table 4 The effect of cupric salts in HEMA primer on the strength of 4-META/MMA-TBBO resin bonding to dentin etched with $10 \%$ phosphoric acid

\begin{tabular}{lcccc}
\hline & \multicolumn{3}{c}{ Bond strength $(\mathrm{MPa})$} & CV** \\
\cline { 2 - 4 } \multicolumn{1}{c}{ Primer } & Mean* & $(\mathrm{SD}) * *$ & Range & $(\%)$ \\
\hline No & $3.8 \mathrm{a}$ & $(2.2)$ & $1.0-6.5$ & 58 \\
$35 \%$ HEMA & $6.3 \mathrm{a}$ & $(3.7)$ & $1.7-10.8$ & 60 \\
Cupric acetate/HEMA $\#$ & $8.7 \mathrm{ab}$ & $(6.9)$ & $3.2-17.1$ & 79 \\
Cupric acetylacetonate/HEMA\# & $9.5 \mathrm{ab}$ & $(4.1)$ & $5.0-15.6$ & 43 \\
Cupric nitrate/HEMA\# & $12.3 \mathrm{~b}$ & $(3.1)$ & $7.9-15.1$ & 25 \\
Cupric chloride/HEMA & $12.5 \mathrm{~b}$ & $(3.4)$ & $8.4-18.5$ & 27 \\
Cupric methacrylate/HEMA & $14.2 \mathrm{~b}$ & $(4.2)$ & $9.3-19.6$ & 30 \\
\hline
\end{tabular}

*, * See Table 2

\# $35 \%$ HEMA primer containing $0.03 \%$ cupric salt.

(3.7 $\mathrm{MPa})(\mathrm{p}>0.05)$. Without the cupric salt in the HEMA primer, the strength of the bonding to dentin treated with $10 \%$ PA was significantly lower $(6.3 \mathrm{MPa}$ vs $12.5 \mathrm{MPa})(\mathrm{p}<$ 0.05). No additional effect of the $\mathrm{Cu}$ primer was noted on the strength of the bond to the dentin treated with the citric acid mixture (11.8 $\mathrm{MPa}$ vs $11.4 \mathrm{MPa})$.

Table 3 summarizes the effect of 4-META in the MMA resin upon bond strength. There were no significant effects of 4-META. Using the $\mathrm{Cu}$ primer, the bond strength was 13.5 $\mathrm{MPa}$ even without 4-META in the resin.

The effect of anions of cupric salts on the bond strengths is compared in Table 4. Cupric methacrylate, chloride, and nitrate increased the bond strength significantly $(p<0.05)(6.3$ $\mathrm{MPa}$ vs 12.3-14.2 $\mathrm{MPa}$ ), but $\mathrm{Cu}$ acetate and acetylacetonate had no significant effect at the level of 0.05 .

\section{DISCUSSION}

In principle, the new $\mathrm{Cu}$ primers could be applied to any treated dentin surface regardless of the agents, in a resin using TBBO initiator. Therefore, we studied how to establish a reasonable and practical treatment procedure. Most current dentin bonding systems contain mild acid cleansers or conditioners. However, enamel bonding systems usually require etching with phosphoric acid (PA) and, therefore, the tooth preparation is a two-step procedure. To prepare enamel and dentin simultaneously would greatly simplify the clinical procedures.

Although aqueous maleic acid, nitric acid, or a mixture of $10 \%$ citric acid and $3 \%$ ferric chloride effectively etch or condition both dentin and enamel for bonding, PA is the preferred agent. This is because phosphate anions would be more physiologically beneficial for the tooth than maleate, nitrate, citrate, and ethylenediamine tetraacetate anion (which are used as mild pretreatment agents in present dentin bonding systems), since they are components of apatite and therefore could be a source of remineralization of the tooth. We therefore selected PA for etching.

Before bonding, we studied changes in the tooth surface after exposure to PA at several concentrations and for various periods. Scanning electron microscopy of the enamel sur- 
faces revealed the gradual progression of etching with an increase in the exposure period and PA concentration. However, 40\% PA for 30 and $60 \mathrm{~s}$ caused considerable destruction of the enamel surface.

Exposure to 5\% PA for $15 \mathrm{~s}$ completely removed the smear layer from the dentin surface and fully opened the tubule orifices. However, the smear plug material in the tubules remained after $60 \mathrm{~s}$. With 10 and $40 \%$ PA, dentin tubules were almost entirely stripped free of the plugs. Considering the surface changes in enamel and dentin, a 30 -second exposure to $10 \%$ phosphoric acid seems optimal for simultaneously etching enamel and dentin. When etched with $7,10,15$, and $40 \% \mathrm{PA}$, there were no significant differences in the bond strength to enamel $(14.5-16.8 \mathrm{MPa})$ and dentin with or without the $\mathrm{Cu}$ primer $(11.3-13.7 \mathrm{MPa}$ or $1.7-4.4$ $\mathrm{MPa}$, respectively) (Tables 1 and 2). As long as the bond strength is the same, a lower concentration of PA would be desirable from the standpoint of pulpal irritation. Thus, etching enamel and dentin simultaneously with $10 \%$ PA for $30 \mathrm{~s}$ seemed optimal. Recently, these conditiona have been adopted and recommended in one commercial bonding system ${ }^{3}$.

The direct application of PA to dentin remains controversial ${ }^{3,4)}$. Adverse pulpal responses have been studied using high concentrations of PA (30-50\%). However lower concentrations of PA could result in different effects. Recent clinical studies have shown a lack of postoperative sensitivity, even when $37 \%$ PA was used to etch dentin ${ }^{5,6)}$. The histologic pulpal response of PA-etched dentin was minimal when the teeth were restored with an appropriate dentin bonding system ${ }^{7,8)}$.

Whereas the high concentrations of PA (30-40\%) usually used to etch enamel cause considerable destruction of the natural dentin structure, low concentrations (5-10\%) do not ${ }^{9}$. Even at $5-10 \% \mathrm{PA}$, the bond strength to enamel is comparable to that obtained with higher concentrations $^{10-12}$. In dentin, with either of the PA concentrations used, the bond strength is not significantly different ${ }^{9.13}$, but the contraction gap between the dentin and the resin is minimized at the lower concentrations ${ }^{9}$. These reported results together with those obtained here indicate that treating teeth with $10 \%$ PA will become more widely acccepted.

In the 4-META/MMA-TBBO resin system, which is supplied commercially in Japan ${ }^{\circledR}$ and the USA ${ }^{\$}$, preparation with PA for enamel and a mixture of $10 \%$ citric acid and $3 \%$ ferric chloride for dentin are usually recommended. However, Tables 1 and 2 show that adding a $\mathrm{Cu}$ primer to the dentin eliminated the need for the citric acid/ferric chloride procedure. Therefore, dentin and enamel can be simultaneously etched. Even if enamel contacts or is contaminated by the primer, it does not seem to cause any adverse effect on the bonding to enamel ; the bond strength to enamel with and without the primer was $16.8 \mathrm{MPa}$ and 19.2 $\mathrm{MPa}$, respectively, after treatment with $10 \% \mathrm{PA}$.

When dentin was treated with PA, the bond strength was increased remarkably by the $\mathrm{Cu}$ primer. In contrast, the bond strength to dentin treated with citric acid/ferric chloride was the same regardless of the $\mathrm{Cu}$ primer $(11.4 \mathrm{MPa}$ vs $11.8 \mathrm{MPa})$. This was reasonable, since ferric ions, which are essential for obtaining strong bond in the present system ${ }^{2}$, had already been supplied from the treatment mixture to dentin collagen. Hence, $\mathrm{Cu}$ (II) ions supplied from the primer showed no additional effect.

(a) Super-Bond C\&B, Sun Medical Co., Moriyama, Shiga, Japan

$\$$ Amalgambond, Parkell Co., Farmingdale, NY, USA 
When the $\mathrm{Cu}$ primer was applied to $10 \%$ PA-treated dentin, a high bond strength of 13.5 $\mathrm{MPa}$ was obtained without 4-META. This value was comparable to that of $11.4 \mathrm{MPa}$ obtained by the standard or recommended bonding procedure for 4-META/MMA resin. A comparison of the bond strengths in the presence and absence of 4-META indicated that adding of 4-META to the MMA-TBBO resin did not significantly improve the bond strength in 4 samples (Table 3). These results again demonstrated the major role of the metal ions and the minor role of 4-META in this dentin bonding system ${ }^{2)}$, although Nakabayashi ${ }^{14}$ has maintained that 4-META improves the bond strength by infiltrating the dentin and forming a dentin-resin hybrid layer.

Adding cupric salts to the HEMA primer markedly improved the bond strength, and no significant difference was indicated among various cupric salts $(p>0.05)$. However, there was a difference in the minimum bond strength and coefficient of variation between the methacrylate, chloride, and nitrate groups, and the acetylacetonate and acetate groups, in which the bond strength was statistically the same as those without primer or with $35 \%$ HEMA primer (9.5 and $8.7 \mathrm{MPa}$ vs 3.8 and $6.3 \mathrm{MPa}$ ) (Table 4). A higher minimum bond strength and lower coefficient of variation are clinically desirable to increase the reliability of the bonding. Not only the variety of anions, but also the concentration of cupric salts should affect the bond strength, though a concentration of $0.03 \%$ was adopted in this study based upon preliminary findings. A detailed study of the effect of concentration of cupric salts has revealed that $0.5-3.0 \times 10^{-4} \mathrm{~mol} / \mathrm{w} \%$ is optimal, resulting in statistically similar bond strengths ${ }^{15)}$. The $0.03 \mathrm{w} / \mathrm{w} \%$ concentration of cupric salts corresponds to $1.15-2.23 \times$ $10^{-4} \mathrm{~mol} / \mathrm{w} \%$ and hence was within the optimal range.

The present study supports our interfacial initiation of polymerization concept, and that the combination of TBBO and metal ions adsorbed on dentin plays a more important and decisive role than 4-META in the bonding to dentin of 4-META/MMA-TBBO resin. Without the metal ions, high bond strength was unobtainable regardless of the presence or absence of 4-META (Table 3).

An adequate amount of metal ions, which can promote polymerization, has to be supplied to dentin before MMA-PMMA-TBBO resin or a similar commercial resin ${ }^{\$ \$}$ to develop strong bonding. The presence of $\mathrm{Cu}$ (II) or $\mathrm{Fe}$ (III) ions adsorbed onto dentin collagen is a prerequisite for obtaining high bond strength in the present bonding system using TBBO as a polymerization initiator. The roles of $\mathrm{Cu}$ (II) or $\mathrm{Fe}$ (III) ions in promoting the TBBO -initiated polymerization of MMA in the presence of collagen and in increasing the bond strength have been discussed in our earlier papers ${ }^{2,16)}$. Essential metal ions can be supplied by using a treatment mixture or primer containing therein. Currently, the primer would be preferable to the treatment solution when the advantage of treating enamel and dentin at the same time with PA is considered. In the future, however, the feasibility of a treatment mixture containing of PA and metal ions remains to be studied.

The $\mathrm{Cu}$ primer that was effective in MMA-TBBO resin should be equally so in other resins, depending on the type of initiator used in each bonding system and resin. Cupric chloride $/ 35 \%$ HEMA primer is effective for two composite resins ${ }^{+17)}$.

\$\$ Super-Bond C\&B, Sun Medical Co., Moriyama, Shiga, Japan

+ Photo bond/Photo Clearfil resin and New bond/Clearfil FII resin, Kuraray Co., Osaka, Japan 
The advantage of interfacial initiation is obvious. Polymerization shrinkage of composite resins causes stress on the bonding system ${ }^{18}$. Therefore, to resist the contraction force of polymerizing resins, polymerization should be initiated rapidly from the dentin interface. Even if the collagen layer is infiltrated by a primer and/or a resin system and a collagen -resin hybrid layer is formed, it does not necessarily lead to strong bonding without interfacial initiation of polymerization, although high bond strength has been discussed in relation to the hybrid layer. A hybrid layer or resin-impregnated dentin, which is clearly present in any bonding system in the range of $0.1-2.5 \mu \mathrm{m}^{19}$, is undoubtedly necessary, but it does not ensure high bond strength. Despite the presence of a hybrid layer, there is a wide range of bond strength for various bonding systems.

The recent findings that moistened dentin was more favorable than dry dentin for improving the bond strength of some dentin bonding systems ${ }^{201}$, would also be better understood on the basis of our concept of interfacial initiation of polymerization. An adequate amount of water in dentin could promote polymerization. In fact, water promoted the polymerization of HEMA in the presence of $\mathrm{N}$-phenylglycine ${ }^{21)}$. Detailed studies are now in progress in our laboratory, and will be reported in the near future.

\section{CONCLUSION}

Primers consisting of HEMA and cupric [Cu (II)] salts capable of promoting the interfacial initiation of polymerization from dentin surfaces, were very effective in bonding dentin etched with $10 \%$ phosphoric acid to 4-META/MMA-TBBO resin. Even without 4-META, the $\mathrm{Cu}$ primer resulted in high bond strength that was comparable to that obtained with the recommended bonding procedure for the resin. Use of the $\mathrm{Cu}$ primer could simplify the bonding procedure by simultaneously treating enamel and dentin with $10 \%$ phosphoric acid.

\section{REFERENCES}

1) Johnson, G. H., Powell, L. V. and Gordon, G. E. : Dentin bonding systems : A review of current products and techniques, JADA $122: 34-41,1991$.

2) Imai, Y., Kadoma, Y., Kojima, K., Akimoto, T., Ikakura, K. and Ohta, T. : Importance of polymerization initiator systems and interfacial initiation of polymerization in adhesive bonding of resin to dentin, J Dent Res 70 : 1088-1091, 1991.

3) Kanca, J.: Improving bond strength through acid etching of dentin and bonding to wet dentin surfaces, JADA 123 : 35-43, 1992.

4) Retief, D. H., Mandras, R. S., Russell, C. M. and Denys, F. R. : Phosphoric acid as a dentin etchant, $A m$ $J$ Dent 5 : 24-28, 1992.

5) Fusayama, T. : Factors and prevention of pulpal irritation by adhesive composite resin restorations, Quintessence Int 18 : 633-641, 1987.

6) Kanca, J. : One year evaluation of dentin-enamel bonding system, $J$ Esthet Dent 2: 100-103, 1990.

7) Willis, G., Cochran, M. and Kafrawy, A.: Pulpal response to dentin acid etching in sealed and unsealed restorations, J Dent Res 71 (Special Issue) : 195 (Abstract No. 717), 1992.

8) White, K., Cox, C., Kanca, J., Farmer, J., Ramus, D. and Snuggs, H. : Histologic pulpal response of acid etching vital dentin, $J$ Dent Res 71 (Special Issue) : 188 (Abstract No. 658), 1992.

9) Chiba, M., Hasegawa, T., Itoh, K. and Wakumoto, S.: The effect of pretreatment of tooth surface on adhesion of a resin bonding system, Japan J Conserv Dent 29 : 219-227, 1986. (in Japanese)

10) Gottlieb, E. W., Retief, D. H. and Jamison, H. C. : An optimal concentration of phosphoric acid as an 
etching agent. I.Tensile bond strength studies, $J$ Prosthet Dent 48: 48-51, 1982.

11) Barkmeier, W., Gwinnett, A. J. and Shaffer, S. : Effects of reduced acid concentration and etching time on bond strength and enamel morphology, $J$ Clin Orthod $21: 395-398,1987$.

12) Retief, D. H. and Denys, F. R. : Adhesion to enamel and dentin, Am J Dent 2: 133-144, 1989.

13) Kanca, J.: Resin bonding to wet substrate. I. Bonding to dentin, Quintessence Int 23 : 39-41, 1992.

14) Nakabayashi, N.: Bonding of restorative materials to dentine : The present status in Japan, Int Dent J 35 : 145-154, 1985.

15) Saito, A. and Imai, Y.: Effect of primer containing copper salt on adhesion of MMA-TBBO resin to dentin, $J$ J Dent Mater 12 (Special Issue 21): 168-169, 1993, (in Japanese)

16) Kadoma, Y., Kojima, K. and Imai, Y.: Polymerization of MMA by TBBO in the presence of ferric chloride-citric acid solution and collagen-A model for adhesion of MMA resins to dentin-, $J J$ Dent Mater 6: 695-701, 1987. (in Japanese)

17) Ikemura, R. and Imai, Y. : Bonding of composite resin to dentin using primer capable of initiating cure from the dentin surface, Japan $J$ Conserv Dent 34 (Autumn Issue) : 17, 1991. (in Japanese)

18) Davidson, C.L., De Gee, A. J. and Feilzer, A.: The competition between the composite-dentin bond strength and the polymerization contraction stress, $J$ Dent Res 63 : 1396-1399, 1984.

19) Van Meerbeek, B., Inokoshi, S., Braem, M., Lambrechts, P. and Vanherle, G.: Morphological aspects of the resin-dentin interdiffusion zone with different dentin adhesive systems, $J$ Dent Res $71: 1530$ $-1540,1992$.

20) Gwinnett, A. J. : Moist versus dry dentin : Its effect on shear bond strength, Am J Dent 5 : 127-129, 1992.

21) Suzuki, A. and Imai, Y.: Role of water in dentin bonding system using N-phenylglycine, $J J$ Dent Mater 12 (Special Issue 21) : 106-107, 1993. (in Japanese) 
2 種の結晶を含有するキャスタブルガラス

セラミックスの機械的強さに及ほすす結晶化の影響

今 政幸, 河野文昭 ${ }^{1}$, 多田芳雄 ${ }^{1}$, 井上三四郎 ${ }^{1}$

浅岡憲三，松本直之 ${ }^{1}$

徳島大学歯学部歯科理工学绕座

'徳島大学歯学部歯科補緅学第一講座

アパタイトとチタン酸マグネシウムの 2 種の結晶が析 出するキャスタフルガラスセラミックスの機械的性質に 及浪す結晶化（セラミング）の影整を検討するため，結 晶化処理温度を変化させ，曲げ強さ，破填靱性および硬 さなどを調へた。その結果，結晶化処理したガラスセラ ミックスの曲げ強さは結晶相の增加につれて高くなるこ とがわかった. ガラスセラミックス中に析出するチタン 酸マグネシウムは同量のアパタイトの析出に比較し, 強
さに対して効果的であることが示唆された。破壊䩓性は アパタイト結晶だけを析出させた試験片で,アスキャス トの場合に比較して，2倍の值が得られた.このことは 硬さの低いアパタイト粒子でもクラックのピン止め効果 を持つものと考えられた。本材料は市販のボティー用陶 材より高い機械的性質が得られたことから，畫美補綴材 料として使用できる可能性が示唆された。

\section{O-メタクリロイル-N-アシルチロシンの合成と無処理人歯象牙質に対する接着性 田仲持郎, 鈴木一臣, 中井宏之 \\ 岡山大学雬学部菌科理工学譳座}

接着性モノマーの分子構造と接着性との相関を調べる ことを目的として,種々の長さのアシル鎖を持つの-メタ クリロイル-N-アシルチロシン (MAATY) を合成, そ れらを含むボンディング绪を調製し，その無処理人蒾象 牙質に対する接着強さについて検討した。そその結果は, チロシン骨格のカルボキシル基の自由度の増大が歯質と の相互作用にとって好ましく強固な接着の要因であると 考えられた，又，立体障害，疎水性といったカルボキシ ル基近傍の棈造, モノマー分子の疎水性一䚇水性のバラ
ンス, 共重合系の重合収縮が重要であることが示唆され た。特に,カルボキシル基の隣接基の立体障害が O-メタ クリロイル-N-オクタノイルチロシンの場合には極めて

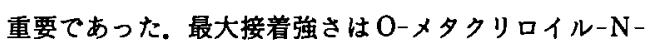
ヘキサノイルチロシン (15 mol \%)-HEMA (85 mol \%) から成るボンディング剤で得られ，その接着強さ(4.75 $\mathrm{MPa})$ はフェニルアラニンを骨格に持つメタクリレート のうちで最大であった.

リン酸で処理した象牙質への接着における銅イオン含有プライマーの効果 今井庸二, 池村竜一郎

東京医科齿科大学医用器材研究所

象牙質界面での重合を促進することが可能な銅イオン を合むプライマーについて検討した，牛雨象牙質表面を $10 \%$ リ酸水溶莈で前処理した後, $0.03 \%$ 銅程を含

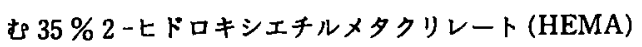

水溶液からなるプライマーを泭布し，4-META/MMATBBO レジンで接着した. このプライマーを用いること により,プライマーを用いないときの接着強さ 3.8 $\mathrm{MPa}$, あるいは銅塩を含まない $35 \%$ HEMA プライマ 
一使用時の 6.3 MPa に比べ, $12.5 \mathrm{MPa}$ の接着強さが, さらにまた, 4-METAを含まないMMA-TBBO レジ

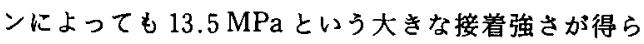
れ，プライマーの有奻性が明らかにされた。銅塩含有プ
ライマーを利用することにより，エナメル質と象牙筫を $10 \%$ \%酸で同時に処理することが可能となり, MMA -TBBO 系レシンンの接着操作の简便化, 確実化に寄与す るものと思わ机る。

\section{磁性アタッチメントの MRI への影響 \\ 飯室隆子フロレンチーナ \\ 東京医科歯科大学医用器材研究所 金属材料部門}

MRI が応用される場合, 撮像領域内に金属, とくに磁 性合金が存在すると，アーチファクトが大きく生じるこ とが，いろいろな文献により，すでに指摘されている。 したがって，磁性アタッチメントのMRIへの影響を詳 細に調べ，明らかにしておくことは，磁性アタッチメン トを、設計，製造し，使用する上で，また，MRI を診断 に用いる上でも大切であると思われる。そこで，磁性ス テンレス鋼として 447Jl，XM27，430の3 種類を用い磁
気特性，寸法，形状のアーチファクトへの影慗を検討し た. その結果, それそれの試料のアーチファクトの中で, $447 \mathrm{Jl}$ が僅かに大きなアーチファクトを生じる傾向を示 し, 形状によるアーチファクトへの差は認められなかっ た.また，寸法とアーチファクトの影䈏距離は比例して いた. 今回の場合では, 材料の透磁率が MRI 画像のアー チファクトに影響したものと思われる.

\section{タンニン・フッ化物合剤を配合したグラスアイオノマーセメントを 作用させた象牙質の F の取り込みと結晶性について 山賀まり子, 小出 武, 稗田豊治 \\ 大阪歯科大学小児歯科学講座}

セメント粉末にタンニン・フッ化物合郕 (HY 剂) を 0 wt \% (HYO), 1.5 wt \% (HY1.5), 5.0 wt \% (HY5) および $10.0 \mathrm{wt} \%$ (HY10) 配合したグラスアイオノマー セメント (GIC) を作用させたウシ象牙質への F の層別 の取り込み量ならびにHYOおよびHY10を作用させ た象牙質の結晶性を調へた。配合割合が高い注ど F の象
牙質への浸透が梁くなり，アパタイトと結合したFの取 り込み量が多かった. 全 F の取り込みに対してFがアパ タイトと安定に結合するのは時間がかかることが示唆さ れた。 また，HY 剤を眍合した GIC を作用させることて 象牙質の結晶性がより向上することが示唆された.

\section{チタン鋳造床作製技法を評価するための実験モデル}

\section{LOW, H. BEST ${ }^{1}$, T. MORI}

Biomaterials Research Unit, Faculty of Dentistry, The University of Sydney

'The Angliss Hospital, Victoria, Australia

チタン鋳造床作製における各種の鋳造方法を評価し， 最適の鋳造法を確立するために，コバルト・クロム鋳造
床の作製に使用されている既製のワックスパターンを用 いる実験モデルを検討した，採用したパターンは厚さ 